1. Liu, H.-X., Cartegni, L., Zhang, M.Q. \& Krainer, A.R. Nature Genet. 27, 55-58 (2001).

2. Ge, H., Zuo, P. \& Manley, J.L. Cell 66 373-382 (1991)

3. Krainer, A.R., Conway, G.C. \& Kozak, D. Cell 66, 383-394 (1991)

4. Fu, X.D. \& Manaitis, T. Proc. Natl Acad. Sci. USA 89, 1725-1729 (1992)

5. Roth, M.B., Zahler, A.M. \& Stolk, J.A. J. Cell Biol. 115, 587-596 (1991).

6. Liu, H.-X., Xhang, M. \& Krainer, A.R. Genes Dev. 12, 1998-2012 (1998).

7. Liu, H.-X., Chew, S.L., Cartegni, L., Zhang, M.Q. \& Krainer, A.R. Mol. Cell. Biol. 20 1063-1071 (2000)

8. Maquat, L. Nature Genet. 27, 5-6 (2001).

9. Arch, R. et al. Science 257, 682-685 (1992).

9. Arch, R. et al. Science 257, $682-685(1992)$.
10. Xu, X. et al. Nature Genet. 22, 37-43 (1999).

11. Carstens, R.P., Wagner, E.J. \& Garcia-Blanco, M.A. Mol. Cell. Biol.20, 7388-7400 (2000). lished, how does one measure levels of the isoform? The presence of a 'spliceoform' can be detected by RT-PCR followed by sequencing or blotting, but this is a laborintensive approach and, with respect to quantification, crude at best.

A high-throughput method that is capable of differentially detecting and measuring levels of splice isoforms would be a welcome development, and not only with respect to having a means to determine what transcripts are spliced and when. One of the most useful applications of expression analysis is the simple but powerful use of profiles in diagnosis and prognosis. Superimposing a 'splice-assay' to query the presence of tumor-associated isoforms ${ }^{9-11}$ would probably heighten the degree of sensitivity of these molecular 'surveys', and provide researchers with a means of determining the general level of splicing activity in a cell. The control of splicing activity per se is not understood, but it seems plausible that the levels of splicing factors in the nucleus determine the rate (in addition to the type) of splicing, and hence the rate of export of mature transcripts into the cytoplasm.

The results of the current study provide insight into molecular mechanism. As genomic sequence is mined and new tools become available, we can look forward to similar studies and a clearer vision of the still largely-obscure world of the transcriptome.

\section{You say tomato, I say tomato}

Pronunciation is a moveable feast, spelling is less so. This month's issue of Nature Genetics is the first to subscribe to American English, rather than British English. Whereas Nature Genetics is an offshoot of the British journal Nature, with which it maintains close ties, it has been based in the United States since its launch in 1992. Nearly nine years on, and with six (soon to be seven) members of staff who are either North American or au fait with the spelling, the decision to adhere to American English is one that is based on practicality. There are three other new features in this issue. The Brief Communication now features a terse abstract so as to increase the odds that it will be picked up by electronic searches. In recognition of the fact that it is a report of primary research, dates of receipt and acceptance are now provided. And Acknowledgments of all research papers will include, should the authors so desire, a specification of who did what-so as to more clearly indicate the nature of their respective contributions. 